\title{
THE RELATIONSHIP BETWEEN BANK LOANS and ECONOMIC GROWTH in TURKEY: 1995-2010
}

\author{
Mahmut ZORTUK * \\ M. Yunus ÇELIK ${ }^{\dagger}$ \\ PhD, Dumlupinar University FEAS, Department of Econometrics, Kütahya \\ PhD, Kastamonu University FEAS, Department of Econometrics, Kastamonu \\ Received: 17 September 2014 \\ Accepted: 15 October 2014
}

\begin{abstract}
In this study, we aim to determine the direction of the relationship between the economic growth and total credits of Turkish Banks. Accordingly, we analyzed this relationship for the period 1995-2010, by using quarterly data analysis. In the analyses as variables, change in the volume of real credits to represent the variable, total credits; and real growth in GDP represents the variable, growth. This study uses Unit Root Test and Gregory-Hansen $(\mathrm{GH})$ Cointegration test as econometric methods. As a result of the analysis and evaluations, it was found that there exists a cointegrating relationship between relevant variables.

Keywords: Bank Loan (BL), Economic Growth (EG), Zivot-Andrews Breakpoint Test (ZABT), Gregory-Hansen(GH) Cointegration test

Jel Code: C4, E51, E43

\section{Özet}

Bu çalışmanın amacı, ekonomik büyüme ve Türkiye'deki Bankalarının toplam kredileri arasındaki ilişkinin yönünü belirlemektir. 1995-2010 dönemine ait üçer aylık verilerin kullanıldığ 1 analizlerde, kredi hacmindeki değişim değişkeni, toplam kredileri temsil etmekte ve GSYİH reel büyüme değişkeni de, büyümeyi temsil etmektedir. Söz konusu iki değişken arasındaki uzun dönemli ilişsinin araştırılmasında Gregory-Hansen (GH) Eşbütünleşme testi kullanılmış ve analiz sonuçlarına göre ilgili değişkenler arasında eşbütünleşme ilişkisinin mevcut olduğu tespit edilmiştir.
\end{abstract}

Keywords: Banka Kredileri (BK), Ekonomik Büyüme (EB), Zivot-Andrews Birim KökTesti (zabt), Gregory-Hansen (GH) Eşbütünleşme testi

\footnotetext{
*mahmut.zortuk@dpu.edu.tr (Corresponding author)

† mycelik@kastamonu.edu.tr
} 


\section{Introduction}

In recent years the financial development has a crucial issue in the economics literature. Many academicians and researches have been made to study the relationship between financial development and economic growth in a both theoretical and empirical framework. The main question is that does financial development promote economic growth or economic growth lead to financial development.

Patrick (1966) finds that bi-directional causality between financial development and economic growth. First direction of causality from financial development to economic growth is labeled as "supply-leading" hypothesis and second direction of causality from economic growth to financial development is labeled as "demandfollowing" hypothesis (Liu and Calderon, 2003). Similarly while findings of King and Levin (1993), Levine et al. (2000), Bittencourt (2012) support to the supply-leading hypothesis, the findings of Gurley and Shaw (1967), Goldsmith (1969) and Jung (1986) advocate demand-following hypothesis (Hassan et al., 2011). In contrast above two, Demetriades and Hussein (1996), Greenwood and Smith (1997), Blackburn and Hung (1998) believe that economic growth and financial development can complement each other making financial deepening and real economic growth mutually causal where there would be bi-directional causality between financial development and economic growth.

The role of finance and bank credit over the influence of economic growth was well known by economists but the issue has been neglected for a long time. 1970s are the period when the importance of credit and finance were rediscovered and emphasized by economists.

The essential function of financial system has realized the funding transfer from overfunding units into the units which needs funding. In this context, the financial system performs its function by means of legal regulations which shapes the behaviors of these units and via financial mediators (Pınar and Ardıç, 2006). The increase and development of financial mediators, the creation of new financial mediators and stable restructuring the financial system with new legal regulations are required to consolidate the reel economy.

In this framework, financial sector or banking sector has significance and critical role in attempting the economic development and growth and the constitution of the capital accumulation because these instruments makes the canalization of the funds derived from these savings into the real investments ( Kandir and İskenderoğlu, 2007).

However, it is compulsory to have parallel development of financial sector with real sector of economy for economic development in any economy. The transfer of usable funds for the investors with indirect way and minimum cost depends upon the healthy operation of financial sector. The finance and placement patterns of real sector, in general meaning, are basic parameters determining the financial architect (Aslan and Korap, 2006).

Hence, the role of financial development and bank credit availability on economic growth has been investigated extensively by researchers. However, the relationship between these two variables has not been resolved and there has been controversy among researchers. It is argued that the role of financial institutions in developed countries is very different from the one they play in developing countries (Arestis and Basu, 2008).

There exists a meaningful effect of financial development on economic growth is questioned in the literature. The relationship between financial development (bank credit is usually used as a proxy) and economic growth involves analytically important and critical policy issues of great relevance. The causality between bank credit and economic growth may run in various directions, depending on how the economists view the working of the economic system at macro level.

There are four basic views to explain the relations between the financial development and economic growth. First view asserts that economic growth leads to the financial development. Here there is "demand following" relations. Firstly economic growth will be realized and funding requirement of economic growth leads the

\footnotetext{
Alphanumeric Journal

The Journal of Operations Research, Statistics, Econometrics and Management Information Systems

ISSN 2148-2225

httt://www.alphanumericjournal.com/
} 
development of financial markets. According to the second view, financial development supports the economic growth. This relation has been defined a relation which "supply leading". The developed character of the financial institutions accelerates and facilitates to convert into the savings for the economy; thus, an economic development by supporting the financial systems. According to the third view, there is a mutual relation between the financial development and economic growth. The last view is that there is a not remarkable and considerable mutual relation between the financial development and economic growth (Altıntaş and Ayrıçay, 2010).

As a result of our analysis, we will try to determine the cointegration of relation between the bank credits and economic growth for a concerned period. This study follows the below-mentioned trajectory: In next section will be presented the literature review, and then the data resources, variables and econometric methodology. The empirical results consist of two different tests of the time series data. The first consists of unit root tests for the stationary properties of the time series data. These are followed by a causality test to indicate the direction of causality between variables. In the last section reveals the concluding remarks.

\section{Literature Review}

The banking sector credit volume and economic growth interaction theoretically and empirically are discussed and especially financial development-economic growth relation is overemphasized. In this line with the increase of the financial means and institutions, a financial development-economic growth relation has been strengthening. For this respect, the developed financial structure shortens the transformation period of savings into the investment and the provision of fund is facilitated by presenting the effective financial means.

Over the past few years the relationship between bank loans and economic growth has been extensively researched. Yet, there seems to be no consensus regarding the direction of causality between bank loans and economic growth. The reasons for this situation are the differences of methods used in analysis of country/countries groups. Below you can find some empirical examples:

Luintel and Khan (1999) studied that the long-run relationship between financial development and economic growth is examined in multivariate vector autoregressive (VAR) model by using 10 sample countries. They found that bi-directional causality between these variables in all sample countries.

Arestis et al. (2001) analyzed the financial development-economic growth relations among the German USA, Japan, Britain and France between 1970-1999 by the method of co- integration and error correction patterns. In analysis, it is concluded that the developments in banking and stock certificates markets increases the economic growth.

Al-Yousif (2002) for the period analyzed 1970-1999 financial development-economic growth relations by using 30 developing countries with panel method and Granger causality test. In research findings, the causality for financial development-economic growth is bidirectional.

Müslümov and Aras (2002) between 1982-2000 in 22 OECD countries analyzed the relations between the development of capital market and economic growth by using panel method and Granger causality test. In this study, the capitalizations of capital market as the measurement of development for capital market and liquidity indicators have been used. As a result of panel method and Granger causality test, it is concluded that development for capital market is directly relevant with the economic growth.

Calderon and Liu (2003) use pooled data of 109 developing and industrial countries from 1960 to 1994 to determine the direction of causality between financial development and economic growth. Ratio of bored money to GDP and ratio of credits provided by financial intermediaries and growth in GDP per capita is used as a proxy for economic growth. They found that generally financial development increase economic growth through rapid capital accumulation and productivity growth, but causality from financial development to economic growth and economic growth lead to financial development both exists. 
Liang and Teng (2006) investigate causality between financial development to economic growth for China over the period 1995-2001 by using multivariate vector autoregressive (VAR) model. The empirical results suggest that there exists a unidirectional causality from economic growth to financial development.

Shahbaz et al. (2008) study that the relationship between stock market development and economic growth in case of developing economy such as Pakistan between 1971 to 2006. They investigate long-run causal linkages and short-run dynamics by using Engle-Granger causality and ARDL tests. Their findings suggested that there is bi-directional causality between stock market development and economic growth.

Abu-Bader and Abu-Qarn (2008) between 1960-2004 analyzed the relations between the financial development and economic growth in Middle Eastern and North African countries including Algeria, Egypt, Israel, Morocco, Syria and Tunisia by using the VAR method and Granger causality tests. In study, one country of the six is exceptional, in all of them, it is arrived that supply priority hypothesis which claims the relations between the development in financial market and economic growth. Just only there is direct causality for Israel to financial market from economic growth.

Enisan and Olufisayo (2009) in seven sub-Sahara countries between the development in stock certificate market and economic growth has been analyzed by the method of ARDL bound test. In this study, between the development in stock certificate market and economic relations, there is a co-integration relation and between the developments in stock certificate market on economic growth has positive effect. In Granger causality tests Egypt and South Africa the development in stock certificate market leads to the economic growth.

Wolde - Rufael (2009), attempt to determine relationship between financial development and economic growth with vector autoregressive (VAR) model for Kenya. The results show that two-way relationship between domestic credit provided by banking sector and economic growth between liquid liabilities and economic growth.

There have been some studies in literature the relations between the development in stock certificate market and economic for respect of Turkey;

Kandır, İskenderoğlu and Önal (2007) in their studies for Turkey between years 1988-2004 by using per three months data related with co-integration analysis. The ratio for the credits given by private sector to nominal gross domestic product (GDP) as the variable expressing the financial development, the ratios of GDP per person as the growth variable has been used. As a result, they determined that, for related period, the direction of the relation form economic growth to financial system.

Acaravc1 at all (2007) in Turkey for 1986-2006 used quarterly data between the financial development and economic growth it is studied with the co-integration method. As a result of analysis, it is found the long term period relation between the financial development and economic growth. As a result of causality, there is onedimensional/directional causality from the financial development to economic growth.

Aslan and Korap (2006) in Turkey the relationship between the financial development and economic growth for the period 1987-2004: VI has been analyzed by using the co-integration and Granger causality techniques. In this study, it is discovered the long period relation between financial development indicators and economic growth used. On the other hand, it is concluded that direction of causality between financial development and economic growth varies in accordance with the indicators for financial development.

Aslan and Küçükaksoy (2006) annually data of 1970-2004 period in Turkey financial development and economic growth has been analyzed and it is concluded the existence of causality from financial development and economic growth.

Finally Ceylan and Durkaya (2010), causality relationships between domestic credit and economic growth has been investigated in Turkey. Granger Causality and Error Correction Model has been used in this analysis including for the period 1998-2008 quarterly time series data. The findings of the study show that there is a bidirectional causality relationship from economic growth to credits.

\footnotetext{
Alphanumeric Journal

The Journal of Operations Research, Statistics, Econometrics and Management Information Systems

ISSN 2148-2225

httt://www.alphanumericjournal.com/
} 
In this context, the main aim is to analyze and examine the relationship between bank credit and economic growth is tested by time-series techniques using quarterly data between 1995Q1 and 2010Q4 for Turkey.

\section{Data and Econometric Methodology}

In our analysis, we used to real percentage changes in GDP $(R G D P)$ as a proxy for economic growth and percentage changes in volume of real credit $(R V C)$ as a proxy for financial development. And in this study uses quarterly data for the period 1995-2010 from the Turkish Statistical Institute (TUIK) and the Central Bank of Republic of Turkey (TCMB), also the data based on 2000=100 index. The variable "credit" used in analysis implies the proportional changes in the volume of real credits used by customers and variable "income" implies the proportional changes in GDP. An overview of the descriptive statistics of our variables is shown in Table 1.

Table 1. Descriptive Statistics of Variables

\begin{tabular}{lcc}
\hline & RGDP & RVC \\
\hline Mean & 6.59494 & 0.312658 \\
Median & 4.040000 & 0.500000 \\
Maximum & 5.520000 & 7.900000 \\
Minimum & -2.120000 & -12.60000 \\
Std. Dev. & 4.06279 & 2.424256 \\
Skewness & 0.145726 & -0.199540 \\
Kurtosis & 3.965953 & 2.96388 \\
Jarque-Bera & 3.350949 & 3.00288 \\
Probability & 0.187219 & 0.45241 \\
Observations & 64 & 64 \\
\hline
\end{tabular}

Empirical studies have agreed that there exists a linear relationship between credit or financial development and economic growth. In order to examine the relationship that exists between credit and economic growth, previous studies have used several analytical approaches such as time series (i.e. VAR models), panel techniques, Engle-Granger causality test. In this study, we use unit root test and Zivot-Andrews test to decide the structural break point and Gregory-Hansen cointegration test as econometric methods to determine relationship between financial development and economic growth.

The period when the analysis has been committed includes the periods of global crises suffered October 2000 in Turkish economy and 2008 in World economy. Impliedly, it is decided to use a test which emphasizes the break in data in determining the properties of stability of the related variable and to consider the structural break in possible changes over the Gross Domestic Product (GDP) and credit usage (RVC).

In response to the test Perron (1990) recommended, it is considered as suitable in Zivot and Andrews test which the structural break has been accepted endogenous is seen more suitable. Hence, Zivot and Andrews test has advantages in comparing with the Perron test etc. Because of this superiority in the study, Zivot and Andrews test has been preferred in determining the unit-root.

On the other hand, our specification of credit usage model may be written as:

\footnotetext{
$\$$ This paper does not detail the Zivot-Andrews test procedure since this is widely applied in the empirical literature.
} 


$$
R V C_{t}=\mu+\alpha_{1} R G D P_{t}+\varepsilon_{t}
$$

The GH approach is an extension of similar tests for unit root tests with structural breaks, for example, by Zivot and Andrews (1992). Gregory and Hansen (GH) propose the cointegration tests which accommodates a single endogenous break in an underlying cointegrating relationship. The four models of Gregory and Hansen (1996a and 1996b) with assumptions about structural breaks and their specifications with two variables (RVC and RGDP), for simplicity, are as follows:

GH-I: Level shift

$$
R V C_{t}=\mu_{1}+\mu_{2} f_{t k}+\alpha_{1} R G D P_{t}+\varepsilon_{t}
$$

GH-II: Level shift with trend

$$
R V C_{t}=\mu_{1}+\mu_{2} f_{t k}+\beta_{1} t+\alpha_{1} R G D P_{t}+\varepsilon_{t}
$$

GH-III: Regime shift where intercept and slope coefficients change

$$
R V C_{t}=\mu_{1}+\mu_{2} f_{t k}+\beta_{1} t+\alpha_{1} R G D P_{t}+a_{11} R G D P_{t} f_{t k}+\varepsilon_{t}
$$

GH-IV: Regime shift where intercept, slope coefficients and trend change

$$
R V C_{t}=\mu_{1}+\mu_{2} f_{t k}+\beta_{1} t+\beta_{2} t f_{t k}+\alpha_{1} R G D P_{t}+a_{11} R G D P_{t} f_{t k}+\varepsilon_{t}
$$

where RVC is the dependent and RGDP is the independent variable, $\mathrm{t}$ is time subscript, $\varepsilon$ is an error term, $\mathrm{k}$ is the break date such that:

$$
f_{t k}=0 \text { if } t \leq k \text { and } f_{t k}=1 \text { if } t>k
$$

The null hypothesis of no cointegration with structural breaks is tested against the alternative of cointegration by the Gregory - Hansen approach.

\section{Empirical Results}

As it is mentioned above, because of the suffering the economic development led to the structural break in 1995-2010 period, the Zivot and Andrews unit-root test has been implemented in variables of credit usage $(R V C)$ and Gross Domestic Product $(R G D P)$. 
Table 2. Z-A Test Results for One Breakpoint

\begin{tabular}{|c|c|c|}
\hline$k=8$ & $\begin{array}{l}\text { RGDP } \\
\text { Model C }\end{array}$ & $\begin{array}{l}\text { RVC } \\
\text { Model A }\end{array}$ \\
\hline $\mathrm{TB}$ & $\begin{array}{c}2000: \mathrm{Q} 4 \\
(\hat{\boldsymbol{\lambda}}=0.67)\end{array}$ & $\begin{array}{c}2008: \mathrm{Q} 4 \\
(\widehat{\boldsymbol{\lambda}}=0.52)\end{array}$ \\
\hline$\alpha$ & $-0.8904(-6.1456)$ & $-1.5469(-5.0994)$ \\
\hline $\boldsymbol{\theta}$ & $-0.3465(-4.1454)$ & $-0.5468(-4.1258)$ \\
\hline$\gamma$ & $0.0338(4.3222)$ & - \\
\hline$k^{*}$ & 4 & 6 \\
\hline Critical Values & - & - \\
\hline$\% 1$ & -4.75 & -4.45 \\
\hline$\% 2.5$ & -4.44 & -4.09 \\
\hline$\% 5$ & -4.18 & -3.76 \\
\hline
\end{tabular}

Note: $\left(k^{*}\right)$ shows the selected length of lag. The values within the bracket are $t$-statistics. The critical values were quoted by ZivotAndrews (1992) Table 2 and Table 4.

Model $\mathrm{C}$ has been estimated for both variables. According to the estimated results of Model $\mathrm{C}$ implemented for Gross Domestic Product (RGDP), it is found significant statistically the estimations of both the parameters $\gamma$ and parameter $\theta$. The result of ZA test depended upon the Model $C$ refers the existence of the break in fourth quarter of 2000 when Turkey suffered from the October 2000 crises. In comparing $\alpha$ parameter with the critical values of Zivot-Andrews (1992), the unit root null hypothesis within level of $1 \%$ significance has been rejected. According to this result, there is not stable effect of October 2000 crisis over GDP. In estimation of Model C for credit usage $(R V C)$, it is determined that the parameter related with the dummy variable (DT) reflected to the trend is not statistically significant. The results of estimations for Model A for the credit usage show the structural break within the last quarter of 2008. Really, it is seen that the proportion for the credit usage for the periods within the last quarter of 2008 and the first two quarters of 2009 decreases. Nevertheless, within the level of $1 \%$ significance for $R V C$ variable, the null hypothesis of unit root has been rejected.

ZA test for the period of 1995Q1-2010Q4 Gross Domestic Product (RGDP) and credit usage (RVC) show that the trend of variables is stable with the break. Çil Yavuz (2006), in order to provide the stability, in similar cases, it is not suitable to take the difference of variables and the results of the may be spurious applied to the causality to the first differences. Çil Yavuz (2006) determined to provide with the below regression estimation regarded the estimated point of break for the stable series:

$$
y_{t}=\mu+\theta D U_{t}+\beta_{t}+\gamma D T_{t}+\tilde{y}_{t}
$$

In above equation $\tilde{y}_{t}$ has the property of stable series been de-trending.

Table 3. Tests for Cointegration with Structural Breaks 1995Q1-2010Q4

\begin{tabular}{llcccc}
\hline \multicolumn{2}{l}{ Break Date } & GH Test Statistics & \multicolumn{2}{c}{$\%$ and $\% 5(\mathrm{CV})^{*}$} & $\mathrm{H}_{0}$ (Reject) \\
\hline GH I & 2000 & 6.11 & -5.13 & -4.61 & Yes \\
GH II & 2000 & -7.22 & -5.45 & -4.99 & Yes \\
GH III & 2000 & -6.96 & -5.47 & -4.95 & Yes \\
GH IV & 2008 & -7.13 & -5.97 & -5.50 & Yes \\
\hline
\end{tabular}

Note: * denotes significant at 5 and 1 percent confidence level using 1-regressors (CV) critical value were quoted by GH(1996a) Table1. 
The results for Gregory-Hansen cointegration tests are given above in Table 3. These results in Table 3 imply that in all the four models with structural breaks, there is cointegration between to real percentage changes in GDP $(R G D P)$ as a proxy for economic growth and percentage changes in volume of real credit $(R V C)$ as a proxy for financial development in Turkey. The brake date is 2000 in GH-I, GH-II GH-III but different at 2008 in GH-I. The null hypothesis of no cointegration is rejected in all the four models.

\section{Concluding Remarks}

In this study, the direction of relation between the credits used by banks and growth is accepted as the most important factor of Turkish financial system. Turkish banking sector has arrived the strong structure by means of the precautions taken after 2001 local crises, in respect of both financial and institutional structure. The operation of banking sector without any problem is one of the most important inputs of the strong economic structure. The essential problem which disrupts the operation of the credit channel in Turkey is the financial deficit in public sector.

According to the results of unit root test (Zivot- Andrews), it is seen that February 2001 and 2008 global crises affected in Turkey negatively in terms of usage credit. On the other hand, according to the results of analyses used in we have used time series approach and the Gregory-Hansen technique for structural breaks to estimate the credit usage for Turkey for the period 1995 to 2010 that there exists a cointegrating relationship between real percentage changes in GDP $(R G D P)$ as a proxy for economic growth and percentage changes in volume of real credit $(R V C)$ as a proxy for financial development after allowing for structural breaks.

These result clearly demonstrate that economic growth has accelerated the credit volume, impliedly, financial development in Turkish economy. The growth increases the saving in one hand, and lessens the cost of loan by decreasing the interest rates. The lack of relevance from the credits towards the growth can be relation with crises suffered in analyzed period, especially 2001 local and 2008 global economic crises.

\footnotetext{
Alphanumeric Journal

The Journal of Operations Research, Statistics, Econometrics and Management Information Systems 


\section{References}

[1]. ARESTIS, P. and BASU, SANTONU, 2008. "Role of finance and credit in economic development" International Handbook of Development Economics Volume one, (ed. Amitava Krishna Dutt and Jaime Ros), Edward Elgar: Northampton.

[2]. ARDIÇ P., DAMAR E." Financial Sector Deepening and Economic Growth: Evidence from Turkey" http://www.luc.edu/orgs/meea/volume9/pdfs/damar\%20ardic\%20-\%20paper.pdf (12.01.2012)

[3]. ABU-BADER, S. and ABU-QARN A.S. (2008). "Financial Development and Economic Growth: Empirical Evidence from Six MENA Countries", Review of Development Economics, 12(4), 803-817.

[4]. ACARAVCI, A., ÖZTÜRK İ. and KAKILLI S.A. (2007). "Finance-Growth Nexus: Evidence from Turkey", International Research Journal of Finance and Economics, 11, 30-40.

[5]. ASLAN, Ö. and KÜÇÜKAKSOY İ. (2006). "Finansal Gelişme ve Ekonomik Büyüme İlişkisi: Türkiye Ekonomisi Üzerine Ekonometrik Bir Uygulama”, Ekonometri ve İstatistik, 4, 12-28.

[6]. ALTINTAŞ, H. and AYRIÇAY Y., (2010), "Türkiye'de Finansal Gelişme ve Ekonomik Büyüme Arasındaki İlişkinin Sınır Testi Yaklaşımıyla Analizi (1987-2007)”, Anadolu Üniversitesi Sosyal Bilimler Dergisi, Sayı:2, Eskişehir, ss.71-98.

[7]. ASLAN, Ö. and KORAP L., (2006), “Türkiye'de Finansal Gelişme ve Ekonomik Büyüme İlişkisi”, Muğla Üniversitesi Sosyal Bilimler Enstitüsü Dergisi; Sayı:17, Muğla, ss.1-20.

[8]. AL-YOUSIF, Y.K. (2002). "Financial Development and Economic Growth: Another Look at the Evidence from Developing Countries", Review of Financial Economics, 11(2), pp.131-150.

[9]. ARESTIS, P., DEMETRIADES, P.O. and LUINTEL, K.B. (2001). "Financial Development and Economic Growth: The Role of Stock Markets", Journal of Money, Credit, and Banking, 33(1), pp.16-41.

[10]. BITTENCOURT, M. (2012). “Financial Development And Economic Growth In Latin America: Is Schumpeter Right?”, Journal Of Policy Modelling, 34 (3), 341-355.

[11]. BLACKBURN, K., HUNG, V.T.Y. (1998) “A Theory Of Growth, Financial Development And Trade”, Economica, 65 (257), 107-124.

[12]. CALDERON, C., LIU, L. (2003). "The Direction Of Causality Between Financial Development And Economic Growth", Journal Of Development Economics, 72(1), 321-334.

[13]. CEYLAN S. and DURKAYA M. (2010 ) Türkiye'de Kredi Kullanımı - Ekonomik Büyüme İlişkisi Atatürk Üniversitesi İktisadi ve İdari Bilimler Dergisi, Cilt: 24, Sayı: 2, 21, ss.21-35

[14]. ÇIL YAVUZ N., (2006) "Test for the effect of tourısm receipts on economıc Growth in Turkey : structural break and causalıty analysıs"Journal of Doğuş University,7(2), pp.162-171

[15]. DEMETRIADES, P.O., HUSSEIN K.A. (1996). "Does Financial Development Cause Economic Growth? Time-Series Evidence From 16 Countries", Journal Of Development Economics, 51(2), 387- 411.

[16]. ENISAN, A. A. and OLUFISAYO, A.O. (2009). "Stock Market Development and Economic Growth: Evidence from Seven Sub-Saharan African Countries", Journal of Economics and Business,61(2), March-April, pp.162-171.

[17]. Gregory, A. W. and Hansen, B. E. (1996a) Residual-based tests for cointegration in models with regime shifts, Journal of Econometrics, 70, 99-126.

[18]. Gregory, A. W. and Hansen, B. E. (1996b) Tests for cointegration in models with regime and trend shifts, Oxford Bulletin of Economics and Statistics, 58, 555-9.

[19]. GREENWOOD, J., SMITH, B.D. (1997). "Financial Markets In Development, And The

[20]. Development Of Financial Markets", Journal Of Economics Dynamics \& Control, 21(1), 145-181.

[21]. HASSAN, M.K., SANCHEZ, B., YU J.S. (2011). "Financial Development And Economic Growth: New Evidence From Panel Data", The Quarterly Review Of Economics and Finance, 51(1), 88-104.

[22]. KANDIR S.Y., İSKENDEROĞLU Ö. and ÖNAL B.Y. (2007), Finansal Gelişme ve Ekonomik Büyüme Arasındaki İlişkinin Araştırılması, Çukurova Üniversitesi Sosyal Bilimler Enstitüsü Dergisi, Sayı:2, ss.311-326.

[23]. LEVINE, R., KING, R.G. (1993). "Finance, Entrepreneurship and Growth”, Journal Of Monetary Economics, 32, 513-542 http://www.econ.brown.edu/fac/Ross_Levine/Publication/1993_JME_Entrepreneurship.pdf (10.09.2013)

[24]. LEVINE, R., LOAYZA, N., BECK, T. (2000). "Financial Intermediation and Growth: Causality and Causes", Journal of Monetary Economics , 46(1), 31-77.

[25]. LIANG, Q., TENG, J.Z. (2006). "Financial Development And Economic Growth: Evidence From China”, China Economic Review, 17(4), 395-411.

[26]. LUINTEL, K.B., KHAN, M. (1999). “A Quantitative Reassessment Of The Finance-Growth Nexus: Evidence From A Multivariate VAR”, Journal Of Development Economics, 60(2), 381-405. 
[27]. MÜSLÜMOV,A. and ARAS,G. (2002)."Sermaye Piyasası Gelişmesi ve Ekonomik Büyüme Arasında Nedensellik İlişkisi:OECD Ülkeleri Örneği”, İktisat İşletme Finans, 17(198), pp.90- 100.

[28]. PERRON, P. (1990). Testing for a unit root in a time series with a changing mean. Journal of Business and Economic Statistics, 8, pp.153-162.

[29]. SHAHBAZ, M., A., N. and Ali L. (2008). "Stock market Development and Economic Growth: ARDL Causality in Pakistan", International Research Journal of Finance and Economics, 14, 182-195.

[30]. WOLDE-RUFAEL, Y. (2009). "Re-Examining The Financial Development And Economic Growth Nexus In Kenya", Economic Modelling, 26(6), 1140-1146.

[31]. ZIVOT, E., ANDREWS, D.W.K., (1992). Further evidence on the great crash, the oil-price shock, and the unit-root hypothesis", Journal of Business \& Economic Statistic, 10, pp.251-270.

[32]. www.tcmb.gov.tr

[33]. www.tuik.gov.tr

The Journal of Operations Research, Statistics, Econometrics and Management Information Systems 